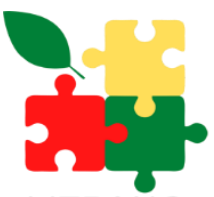

LITBANG Edusaintech

\section{Jurnal Litbang Edusaintech (JLE)}

http://journal.pwmjateng.com/index.php/jle

\title{
Polip Septochoana Eosinofilik: Studi Kasus
}

\author{
${ }^{1}$ Renny Swasti Wijayanti, ${ }^{1}$ Andriana Tjitria Widi Wardani, ${ }^{1}$ Dina Fatmawati \\ ${ }^{1}$ Bagian Imu THT, Fakultas Kedokteran, Universitas Islam Sultan Agung \\ * Correspondence: E-mail: dienafatma@unissula.ac.id
}

\begin{abstract}
A B S T R A C T S
Nasal polyps are chronic inflammatory condition of the nose and paranasal sinuses, which is indicated by benign prolapsed mucosal lesions arise from lateral walls of the nose and the paranasal sinuses. Polyps originating from the medial aspect of nasal septal are extremely rare and present a diagnostic dilemma. We present a 54-year-old woman with nasal polyp originating from the medial aspect of the nasal septum. The diagnosis of an eosinophilic septochoanal polyp was made on histopathological examination after surgical excision of the mass. Most polyps originate from the lateral walls of the nasal passage. Isolated nasal septal polyps are rare but can cause symptoms such as nasal obstruction and olfactory disorders. An extremely rare cases, like the one presented here, where the site of origin is from an unusual site like the medial aspect nasal septum, and the exact cause is still unknown.
\end{abstract}

A RTICLE INFO

History of articles:

Sent: 26 Oktober 2021

Accepted: 28 Oktober 2021

Publish Online: 30 Oktober 2021

Keyword: nasal polyps, eosinophile

\section{A B S T R A K}

Polip nasi adalah peradangan kronis pada mukosa hidung dan sinus paranasal, yang ditandai dengan adanya prolaps lesi jinak mukosa serta infiltrasi sel - sel inflamasi. Polip nasi yang berasal dari aspek medial dari septum nasi sangat jarang terjadi. Tujuan penelitian ini adalah untuk menelaah lebih lanjut kasus polip septochoana eosinofilik yang jarang sekali dijumpai. studi kasus polip nasi. Dilaporkan satu kasus seorang wanita berusia 54 tahun, yang mengalami keluhan hidung tersumbat serta penurunan penghidu, setelah dilakukan pemeriksaan naso endoskopi dan CT - scan sinusparanasal didapatkan adanya massa yang berasal dari aspek medial septum nasi bilateral yang meluas hingga choana. Diagnosis polip septochoana eosinofilik ditegakkan berdasarkan hasil pemeriksaan histopatologi setelah dilakukan tindakan eksisi massa. Pasien dilaporkan tidak mengalami kekambuhan setelah dilakukan evaluasi selama 6 bulan pasca operasi. Pada umumnya polip berasal dari dinding lateral rongga hidung, polip yang berasal dari aspek medial septum nasi, seperti pada kasus yang dilaporkan sangat jarang terjadi dan perlu ditelaah lebih lanjut.

Keyword: polip nasi, eosinofil 


\section{INTRODUCTION}

Polip nasi adalah suatu massa yang terjadi akibat inflamasi yang berhubungan dengan mukosa rongga hidung atau sinus paranasal. Polip nasi terbentuk dari akumulasi cairan ekstraseluler, proliferasi submukosa dan mukosa di dalam hidung ataupun sinus paranasal sebagai akibat dari proses inflamasi kronis. ${ }^{1,23}$ Prevalensi polip nasi yang paling banyak ditemukan di meatus media dan sinus ethmoid pada populasi dewasa dan mempengaruhi 1 hingga 4\%. diduga berkontribusi pada patogenesisnya, seperti peradangan pada mukosa akibat adanya obstruksi sinus atau alergi karena aliran udara yang berubah disertai dengan adanya peningkatan tekanan udara. ${ }^{6,7}$

Salah satu bentuk polip nasi yang muncul dari mukosa dekat sinus maksilaris dan meluas ke arah choana dengan tangkai tunggal disebut polip antrochoana. Polip tersebut dapat meluas ke nasofaring atau bahkan hingga orofaring. Sedangkan polip nasi yang berasal dari septum nasi dikenal dengan polip septochoana. Polip nasi ini biasanya unilateral, jinak, dan menyerang melalui rongga hidung posterior ${ }^{8}$

Eosinofil telah lama dikenal berhubungan dengan sebagian besar kasus polip nasi di Eropa dan Amerika Serikat, yang seringkali ditandai dengan munculnya respon imun sel $\mathrm{T}$ - helper $(T h-2) .{ }^{3}$ Di negara Barat dilaporkan eosinofil mencakup lebih dari $60 \%$ sel inflamasi pada pasien yang mengalami polip nasi. Secara klinis polip nasi seringkali dihubungkan dengan asma dan alergi. Namun demikian, hubungan antara adanya alergi dengan patogenesis polip nasi masih belum begitu jelas. ${ }^{4,5}$

Lesi bilateral yang muncul dari aspek medial septum nasi dan tumbuh meluas ke arah choana, seperti kasus yang disajikan di sini sangat jarang terjadi dan dapat menimbulkan dilema dalam menentukan diagnosis, serta diperlukan pemeriksaan naso endoskopi, pemeriksaan penunjang seperti radiologis Computed tomography (CT) - scan sinus paranasal dan pemeriksaan histopatologis untuk menyimpulkan diagnosis.
Tujuan penulisan laporan kasus ini adalah untuk menelaah lebih lanjut kasus polip septochoana eosinofilik yang jarang sekali dijumpai.

\section{METHODS}

Seorang wanita berusia 54 tahun datang memeriksakan diri ke poliklinik THT Rumah Sakit Islam Sultan Agung Semarang dengan keluhan hidung tersumbat sejak tiga bulan yang lalu. Keluhan hidung tersumbat dirasakan pada kedua sisi, dan semakin lama semakin memberat. Keluhan juga disertai dengan pilek berwarna putih jernih, encer, tidak berbau, tidak disertai adanya mimisan maupun nyeri pada wajah dan sekitar mata. Selain itu, pasien juga mengalami gangguan penurunan fungsi penghidu. Keluhan pada telinga dan tenggorok disangkal. Tidak didapatkan adanya riwayat alergi, asma, maupun peradangan paru.

Pada pemeriksaan fisik didapatkan keadaan umum pasien baik, pemeriksaan hidung luar tidak tampak adanya deformitas pada hidung, palpasi maupun perkusi sinus paransal tidak didapatkan keluhan nyeri. Dari pemeriksaan naso endoskopi menunjukkan adanya massa yang timbul dari bagian medial septum nasi di kedua kavum nasi yang meluas hingga choana. Massa tersebut memiliki konsistensi padat, tidak rapuh, dan tidak mudah berdarah saat disentuh. Tidak tampak adanya kelainan ataupun massa dari meatus media.

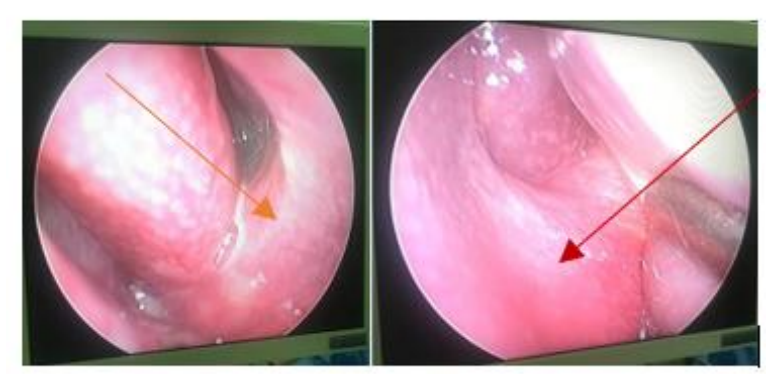

Gambar 1. Pemeriksaan naso endoskopi pada kavum nasi bilateral memperlihatkan adanya massa yang berasal dari bagian medial septum nasi yang meluas ke arah choana (panah).

Pada pemeriksaan CT - scan sinus paranasal menunjukkan adanya lesi isodens di kedua kavum nasi yang mengalami perluasan 
hingga ke arah choana, berbatas tegas, tidak ada destruksi jaringan sekitar, serta tidak dijumpai adanya keterlibatan sinus paranasal yang mengalami kelainan

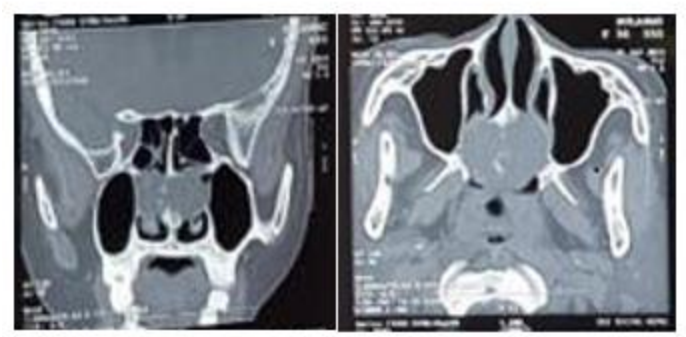

(a)

(b)

Gambar 2. Pemeriksaan CT - scan sinus paranasal, (a) pada potongan coronal tampak lesi isodens di kedua kavum nasi yang meluas hingga choana serta tidak ada destruksi jaringan sekitar. (b) pada potongan axial tampak lesi isodens yang meluas hingga choana.

Pada pasien dilakukan tindakan operatif, yaitu tindakan eksisi massa dengan menggunakan guiding naso endoskopi dan di bawah anestesi umum. Dasar lesi diangkat dengan menyisakan jaringan yang sehat. Kemudian pada lesi dilakukan pemeriksaan histopatologi. Setelah dilakukan tindakan operatif, diberikan terapi kortikosteroid intransal, serta dianjurkan untuk melakukan kontrol secara berkala. Dari pemeriksaan histopatologi menunjukkan polip eosinofilik kronis. Setelah dilakukan evaluasi paska operasi selama 6 bulan, tidak dijumpai adanya tanda tanda kekambuhan pada pasien.

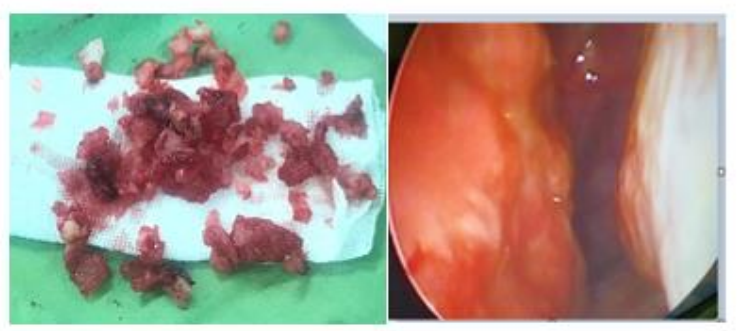

(a)

(b)

Gambar 3. Gambar (a) menunjukkan gambaran makroskopis lesi. Gambar (b) menunjukkan kondisi kavum nasi setelah dilakukan tindakan operatif.

\section{RESULTS AND DISCUSSION}

Sebagian besar, polip nasi muncul dari dinding lateral mukosa rongga hidung dari meatus media, juga pada area yang kontak dengan procesus uncinatus, atau di sinus ethmoid anterior. ${ }^{9}$ Kasus pertama adanya polip nasi yang berasal dari septum nasi dilaporkan oleh Bailey pada tahun $1979 .{ }^{10}$ Selanjutnya, pada tahun 2003 juga dilaporkan adanya polip nasi yang meluas ke choana yang berasal dari septum nasi oleh Ozgirgin pada tahun 2003. ${ }^{11}$

Pada kasus yang dilaporkan, lokasi asal dari polip nasi merupakan salah satu lokasi polip yang jarang dijumpai, yaitu pada aspek medial septum nasi, dan munculnya bilateral serta meluas ke arah choana, sedangkan pada lokasi tersebut memiliki kontak yang minimal terhadap bagian hidung lainnya. Kasus serupa dari polip nasi akibat alergi yang terkait dengan kondisi deviasi septum nasi dilaporkan oleh Vinayak S (2006). Dimana pada kasus tersebut, adanya penyebab kelainan anatomi seperti deviasi septum nasi diduga berperan penting sebagai predileksi munculnya polip nasi, karena deviasi septum nasi dapat mengubah aliran udara di dalam hidung. ${ }^{11,12}$ Pada kasus yang dilaporkan saat ini, tidak ada deviasi septum nasi seperti yang terlihat dari pemeriksaan naso endoskopi maupun gambaran pemeriksaan CT - scan sinus paranasal.

Faktor etiologi polip nasi yang paling banyak berperan adalah gangguan respon inflamasi pada lapisan mukosa akibat alergi dan inflamasi kronik. ${ }^{10}$ Gambaran histopatologi dari polip nasi meliputi inflamasi dari sel $\mathrm{T}$ helper (Th)2 diikuti oleh adanya infiltrasi eosinofil, penebalan membran basalis, dan hiperplasi epitel. ${ }^{8,9}$ Pada kasus yang dilaporkan, dari pemeriksaan histopatologi pasca bedah eksisi ditemukan massa polipoid yang ditutupi oleh epitel transisional, stroma fibromuskular serta mengandung kelenjar hiperplastik yang didominasi oleh eosinofil, limfosit dan histiosit, sesuai dengan gambaran polip nasi eosinofilik. Pemeriksaan histopatologi ini dianggap sebagai tipe histologis yang paling umum ditemukan hingga 86\% kasus. Sel - sel inflamasi biasanya muncul dalam jumlah sedang, tetapi terkadang dapat ditemukan dalam jumlah besar. Hasil tersebut kemungkinan berhubungan dengan 
peningkatan profil sitokin Th2, seperti Interleukin (IL - 4) dan IL $-5 .{ }^{5}$ Meskipun pada kasus ini tidak dijumpai adanya riwayat alergi pada pasien, kemungkinan timbulnya polip nasi pada pasien tersebut disebabkan oleh adanya paparan insektisida berulang selama pasien bekerja sebagai petani, dimana paparan tersebut mengakibatkan stimulasi inflamasi kronis pada mukosa hidung maupun sinus paranasal, sehingga dapat menyebabkan terbentuknya polip nai.

Penatalaksanaan polip nasi difokuskan pada penggunaan steroid oral dan intranasal. Pasien yang mengalami kegagalan dalam penggunaan terapi tersebut, disarankan untuk dilakukan tindakan operatif dengan guiding naso endoskopi, kemudian diikuti dengan terapi intranasal steroid untuk mencegah kekambuhan. ${ }^{3,13,14}$ Penatalaksanaan pasien pada kasus ini yaitu dengan tindakan bedah eksisi guiding naso endoskopi, kemudian pada jaringan yang didapat dilanjutkan pemeriksaan histopatologi untuk menegakkan diagnosis.
Pada tindak lanjut rutin pasca operasi, untuk mencegah kambuhnya kasus ini, selain digunakan kortikosteroid intranasal, pasien harus menghindari alergen serta faktor pemicu yang dapat menstimulasi peradangan kronis sehingga dapat mengakibatkan pembentukan polip berulang.

\section{CONCLUSION}

Polip nasi yang berasal dari aspek medial septum nasi yang meluas hingga choana sangat jarang terjadi. Penegakkan diagnosis polip septochoana eosinofilik didapatkan setelah pemeriksaan histopatologi pasca tindakan reseksi

Penelitian selanjutnya diharapkan dapat mendeteksi alergen serta faktor pemicu terjadinya alergi guna mengevaluasi patogenesis polip nasi secara definitif, sehingga dapat mengembangkan strategi penatalaksaan yang tepat.

\section{REFERENCES}

1. Salaria N, Sharma N, Garg, U., Saluja, S.K. \& Agarwal, R. Inflammatory Septal Nasal Polyp. Iran J Otorhinolaryngol. 2015; 27: 319-323.

2. Al Jobran, B.S., Alotaibi, A.E., Asiri, A.Y. Nasal Polyps and its Histo-pathological Evaluation. The Egyptian Journal of Hospital Medicine. 2018 ; 70 (11): 2022-2024.

3. Nacleiro RM, Baroody FM, Pinto JM. Nasal Polyps and Biomarkers. J Allergy Clin Immunol Pract. $2017 ; 5: 1589-90$.

4. Jeong WJ, Lee CH, Cho SH, Rhee CS. Eosinophilic Allergic Polyp: A Clinically Oriented Concept of Nasal Polyp. Otolaryngology - Head and Neck Surgery. 2010; 144 (2) : 241 246.

5. Sun C, Ouyang H, Lou R. Distinct characteristics of nasal polyps with and without eosinophilia. Braz J Otorhinolaryngol. $2017 ; 83$ (1) : $66-72$.

6. Jahromi, AM, Pour AS. The Epidemiological and Clinical Aspects of Nasal Polyps that Require Surgery. Iran J Otorhinolaryngol. 2012; 2(24) : 75 - 78. 